\title{
Relaksasi Otot Progresif untuk Mengurangi Gejala Fatigue pada Klien Diabetes Mellitus Tipe 2 di Wilayah Kerja Pusat Kesehatan Masyarakat Kayon
}

\section{Progressive Muscle Relaxation to Reduce Fatigue Symptoms in Type 2 Diabetes Mellitus Clients in the Working Area of the Kayon Community Health Center}

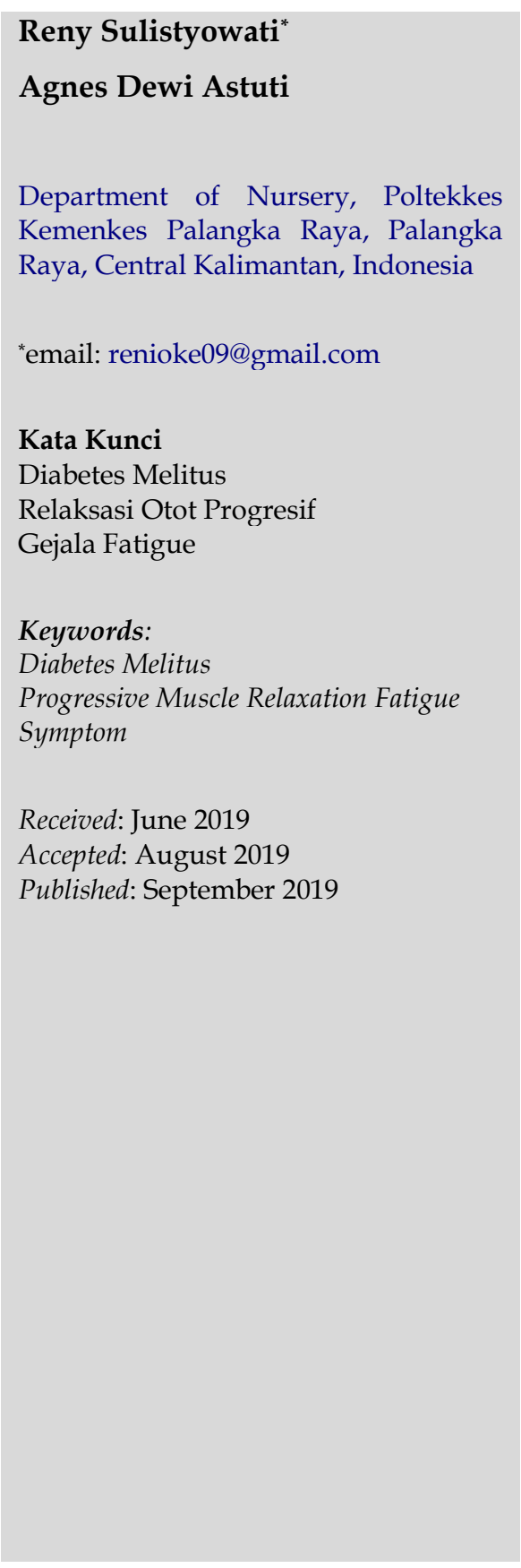

\begin{abstract}
Abstrak
Diabetes melitus (DM) merupakan sekelompok kelainan heterogen yang ditandai oleh kenaikan kadar glukosa dalam darah atau hiperglikemia. Gejala fatigue adalah salah satu keluhan klinis yang meluas di antara orang dewasa dengan diabetes tipe 2, hal ini dikaitkan dan dilaporkan buruk terhadap kesehatan dan merupakan hambatan utama bagi keberhasilan pengelolaan diabetes. Fluktuasi kadar glukosa juga dapat menyebabkan kelelahan. Relaksasi otot progresif merupakan salah satu teknik relaksasi yang mudah dan sederhana. Berdasarkan penelitian yang pernah dilakukan, relaksasi otot progresif salah satunya dapat membantu menurunkan gejala fatigue pada klien DM Tipe 2. Kegiatan pengabdian kepada masyarakat dilaksanakan di Wilayah Kerja PKM Kayon tepatnya di Posbindu Bethesda pada 30 orang peserta. Pelaksanaan kegiatan diantaranya adalah memberikan pelayanan kesehatan berupa pengukuran tekanan darah dan pemeriksaan kadar glukosa darah, pemberian pendidikan kesehatan tentang DM dan mengajarkan relaksasi otot progresif. Media yang digunakan adalah leaflet dan booklet. Peserta antusias mengikuti kegiatan dari awal sampai akhir. Evaluasi yang telah dilakukan, hasil post test untuk pengetahuan tentang DM terdapat peningkatan nilai rata-rata pengetahuan sebesar $17,85 \%$.
\end{abstract}

\begin{abstract}
Diabetes mellitus (DM) is a group of heterogeneous disorders characterised by increases in blood glucose levels or hyperglycemia. Symptoms of fatigue are a widespread clinical complaint among adults with type 2 diabetes, this is associated with and reported to be bad for health and is a significant obstacle to the successful management of diabetes. Fluctuations in glucose levels can also cause fatigue. Progressive Muscle Relaxation is one of the natural and simple relaxation techniques. Based on the research that has been done, Progressive Muscle Relaxation can help to reduce fatigue symptoms in Type 2 DM clients. Community service activities were carried out in the PKM Kayon Working Area, precisely at Posbindu Bethesda for 30 participants. The activities include providing health services in the form of blood pressure measurement and blood glucose level examination, providing health education about DM and teaching progressive muscle training. The media used are leaflets and booklets. Participants enthusiastically participated in the activities from the beginning to the end. The evaluation that has been done, the post-test results for knowledge of DM have an increase in the average value of expertise by $17.85 \%$.
\end{abstract}




\section{PENDAHULUAN}

Diabetes melitus (DM) merupakan salah satu penyakit kronis yang dari tahun ke tahun jumlah penderitanya semakin banyak. Pola makan yang telah bergeser dari pola makanan tradisional yang mengandung banyak karbohidrat dan serat dari sayuran, ke pola makan modern dengan komposisi makanan yang terlalu banyak mengandung protein, lemak, gula, garam, dan mengandung sedikit serat. Pola makan tidak berimbang seperti inilah yang dapat menyebabkan terjadinya penyakit DM (Kristianungrum \& Budiyani, 2011). Diabetes melitus adalah suatu kelompok penyakit metabolik dengan karakteristik hiperglikemia yang terjadi karena kelainan sekresi insulin, gangguan kerja insulin atau keduanya, yang menimbulkan berbagai komplikasi kronik pada mata, ginjal, saraf dan pembuluh darah (American Diabetes Association, 2009). Diabetes melitus merupakan sekelompok kelainan heterogen yang ditandai oleh kenaikan kadar glukosa dalam darah atau hiperglikemia. Pada DM, kemampuan tubuh untuk bereaksi terhadap insulin dapat menurun atau pankreas dapat menghentikan sama sekali produksi insulin (Kunaryanti et al., 2018). Keadaan ini menimbulkan hiperglikemia yang dapat mengakibatkan komplikasi metabolik akut seperti diabetes ketoasidosis dan sindrom hiperglikemik hiperosmolar non-ketotik (HHNK). Hiperglikemia jangka panjang dapat ikut menyebabkan komplikasi mikrovaskuler yang kronis (penyakit ginjal dan mata) dan komplikasi neuropati (penyakit pada saraf). Diabetes juga disertai dengan peningkatan insiden penyakit makrovaskuler yang mencakup infark miokard, stroke dan penyakit vaskuler perifer (American Diabetes Association, 2009).

Di berbagai negara terjadi peningkatan prevalensi Diabetes Mellitus Tipe 2 yang cukup tinggi. Indonesia merupakan salah satu negara dengan angka prevalensi
DM Tipe 2 ke tujuh terbanyak di dunia dengan angka 8,5 juta penderita setelah Cina (98,4 juta), India (65,1 juta), Amerika (24,4 juta), Brazil (11,9 juta), Rusia (10,9 juta), Mexico (8,7 juta), Indonesia ( 8,5 juta), kemudian diikuti Jerman (7,6 juta), Mesir (7,5 juta), dan Jepang (7,2 juta) (Rudijanto, 2014).

Kelelahan adalah keluhan klinis yang meluas di antara orang dewasa dengan diabetes tipe 2, hal ini telah dikaitkan langsung dengan kesehatan yang dilaporkan buruk dan kemungkinan merupakan hambatan utama bagi keberhasilan pengelolaan diabetes. Meskipun demikian, ada beberapa data menggambarkan besarnya, keparahan, atau etiologi kelelahan terkait diabetes (Fritschi et al., 2012). Fluktuasi kadar glukosa juga dapat menyebabkan kelelahan. Ada bukti yang berkembang bahwa individu dengan DM tipe 2 mengalami glukosa postprandial yang tinggi, bahkan pada subjek dengan nilai hemoglobin A1C dalam kisaran memuaskan $(<7.0 \%)$. Fluktuasi glukosa postprandial dapat merangsang sitokin proinflamasi dan stres oksidatif, keduanya telah dikaitkan dengan gejala kelelahan (Setiawan, 2011). Dalam sebuah penelitian tentang gejala dan kadar glukosa darah orang dewasa dengan DM tipe 2 melaporkan tingkat gejala fisik tertinggi (termasuk kelelahan) selama satu jam pertama setelah makan, menunjukkan adanya hubungan antara gejala dan tingkat perubahan glukosa. Temuan dari penelitian ini menunjukkan bahwa ada hubungan antara fluktuasi kadar glukosa darah dengan fatigue/kelelahan (Amir et al., 2015).

Beberapa faktor yang dihubungkan dengan kelelahan pada pasien diabetes, termasuk faktor fisiologis misalnya hipoglikemia atau hiperglikemia, faktor psikologis seperti depresi dan kesusahan terkait dengan penyakit ini. Faktor epidemiologi seperti usia dan latar belakang pendidikan dan faktor terkait kesehatan (misalnya durasi penyakit dan riwayat komorbiditas. 
Hipoglikemia yang sering terjadi selama pengobatan diabetes sering dicurigai menjadi penyebab kelelahan (Seo et al., 2015). Pengelolaan diabetes melitus terdiri dari edukasi, perencanaan makan, olahraga dan intervensi farmakologis. Langkah pertama dalam mengelola diabetes melitus selalu dimulai dengan pendekatan non farmakologis, yaitu melakukan tindakan seperti tidak makan berlebihan, menjaga berat badan, dan rutin melakukan aktivitas fisik. Olahraga juga dapat secara efektif mengontrol diabetes, antara lain dengan melakukan senam khusus diabetes, berjalan kaki, bersepeda, dan berenang (Asif, 2014). Diet di padu dengan olahraga merupakan cara efektif mengurangi berat badan, menurunkan kadar gula dan mengurangi stres. Latihan yang dilakukan secara teratur dapat menurunkan tekanan darah, kolesterol dan risiko terkena serangan jantung, serta memacu pengaktifan produksi insulin dan membuatnya bekerja lebih efisien,sehingga memungkinkan para penyandang diabetes dapat tetap hidup normal seperti bukan penyandang diabetes (Soegondo et al., 2007).

Progressive Muscle Relaxation (PMR) atau relaksasi otot progresif merupakan salah satu terapi nonfarmakologis yang dapat diaplikasikan untuk mengurangi gejala fatigue atau kelelahan pada klien DM. Relaksasi Otot Progresif adalah gerakan mengencangkan dan melemaskan otot-otot pada satu bagian tubuh pada satu waktu untuk memberikan perasaan relaksasi secara fisik (Lindquist et al., 2014). Relaksasi otot progresif merupakan salah satu teknik relaksasi yang mudah dan sederhana. PMR merupakan suatu prosedur untuk mendapatkan relaksasi pada otot melalui dua langkah yaitu dengan memberikan tegangan pada suatu kelompok otot dan menghentikan tegangan tersebut kemudian memusatkan perhatian pada bagaimana otot tersebut menjadi rileks, merasakan sensasi rileks dan ketegangan menghilang (Livana et al., 2018).
Hasil penelitian Antoni et al. (2016) didapatkan hasil pada 33 responden kelompok kontrol dan 33 orang kelompok intervensi, terdapat perbedaan gejala fatigue yang signifikan sebelum dan sesudah pemberian PMR pada kelompok intervensi $(\mathrm{t}=43,57, \mathrm{p}=<0.001)$; kelompok kontrol $(t=1,73, p=0,093)$ dan ditemukan perbedaan gejala fatigue yang signifikan pada kelompok intervensi dengan kelompok kontrol, $t=30,453$, $\mathrm{p}=<0,001$, sehingga dapat disimpulkan PMR dapat menurunkan gejala fatigue pada klien DM tipe 2. Penelitian lainnya terkait aplikasi relaksasi otot progresif adalah penelitian oleh Danismaya (2009) pada 20 orang kelompok intervensi dan 20 orang kelompok kontrol didapatkan hasil pengaruh relaksasi yoga menunjukkan perbedaan diantara kedua kelompok dengan nilai p 0,001 di hari ke3 serta nilai p 0,000 di hari ke-4 dan ke-5 dalam 95\% tingkat kepercayaan. Teknik relaksasi yoga disimpulkan mempunyai pengaruh untuk mengurangi keluhan fatigue pada pasien kanker pasca kemoterapi. Perawat berperan penting dalam upaya memberikan edukasi dan memperkenalkan penggunaan terapi nonfarmakologis dalam hal ini relaksasi otot progresif sebagai salah satu upaya untuk membantu mengurangi kelelahan yang sering dialami klien DM (Fahra et al., 2017). Adapun tujuan dari kegiatan Pengabdian kepada masyarakat ini adalah untuk memperkenalkan Teknik relaksasi otot progresif pada klien penderita DM tipe 2 di wilayah kerja PKM Kayon Palangka Raya.

\section{METODOLOGI}

Pengabdian masyarakat dilakukan diawali dengan memberikan pendidikan kesehatan tentang penyakit DM, kemudian dilanjutkan dengan mengajarkan gerakan relaksasi otot progresif untuk mengatasi gejala fatigue yang sering dialami pasien DM tipe 2. Kegiatan dilaksanakan di Posbindu Bethesda yang merupakan salah satu binaan Puskesmas Kayon. Kegiatan 
dilaksanakan pada Bulan November 2018. Tujuan kegiatan pengabdian kepada masyarakat ini sebagai salah bentuk aplikasi terhadap hasil penelitian yang telah dilakukan sebelumnya yaitu tentang Pengaruh PMR Terhadap Gejala Fatigue Pada Klien DM Tipe 2. Manfaat dari kegiatan ini bagi klien DM tipe 2 secara khusus dan bagi masyarakat secara umum, dapat mengenal salah satu terapi non-farmakologis untuk mengatasi gejala fatigue sehingga klien dan masyarakat tidak tergantung pada obat untuk mengatasi masalah fatigue.

Pelaksanaan kegiatan dengan menggunakan metode ceramah dan tanya jawab. Media yang digunakan adalah booklet dan leaflet. Kegiatan diawali dengan pembagian kuesioner (pre-test) untuk mengetahui sejauh mana pengetahuan peserta tentang penyakit DM dilanjutkan dengan penjelasan tentang penyakit DM kemudian tanya jawab. Kegiatan kemudian dilanjutkan dengan demonstrasi sekaligus bersama-sama mempraktikkan gerakan relaksasi otot progresif. Setelah beristirahat kurang lebih 10 menit dilanjutkan dengan pembagian kuesioner (post-test). Tim pelaksana kegiatan pengabdian kepada masyarakat terdiri dari dosen dan Mahasiswa Prodi D-IV Keperawatan Poltekkes Kemenkes Palangka Raya berjumlah 10 orang. Masingmasing tim pelaksana ada yang bertugas sebagai pembawa acara, fasilitator, seksi dan dokumentasi.

\section{HASIL DAN PEMBAHASAN}

Kegiatan dihadiri oleh 30 peserta dan 3 orang kader serta berjalan dengan tertib. Peserta antusias mengikuti kegiatan dari awal hingga akhir kegiatan. Berikut tahap kegiatan yang dilakukan:

1. Kegiatan diawali dengan senam bersama dilanjutkan dengan pemberian pelayanan kesehatan berupa pengukuran tekanan darah dan pemeriksaan kadar glukosa darah.
2. Selanjutnya perkenalan anggota tim dan menyampaikan tujuan kegiatan.

3. Acara dilanjutkan Pemberian kuesioner (pre-test) kepada responden untuk menggali pengetahuan peserta tentang DM setelah itu pemberian pendidikan kesehatan tentang DM yang kemudian dilanjutkan dengan mengajarkan gerakan relaksasi otot progresif sekaligus langsung mempraktikkan bersama peserta, dilanjutkan diskusi dan tanya jawab. Setelah istirahat kurang lebih 10 menit, dilanjutkan pemberian kuesioner (post-test) tentang penyakit DM.

4. Kegiatan berikutnya adalah pembagian booklet yang berisikan penjelasan tentang relaksasi otot progresif beserta langkah-langkah gerakannya.

5. Terminasi akhir adalah evaluasi kegiatan dan diakhiri sesi foto bersama. Tidak lupa tim memberikan penjelasan agar relaksasi dilakukan dirumah minimal seminggu 3 kali agar dapat dirasakan manfaatnya.

Berdasarkan hasil pre test dan post tes dapat dilihat terdapat peningkatan nilai rata-rata pengetahuan setelah dilakukan pendidikan kesehatan sebesar 17,85\%, sebagaimana disajikan pada Tabel I.

Tabel I. Nilai Pengetahuan tentang DM

\begin{tabular}{lcc}
\hline \multicolumn{1}{c}{ Nilai } & Pre-test & Post-test \\
\hline Rata-rata & 74,67 & 88 \\
Tertinggi & 90 & 100 \\
Terendah & 50 & 80 \\
\hline Peningkatan & $(88-74.67) / 74.67=17,85$ \\
\hline
\end{tabular}

Relaksasi otot progresif dan variasi relaksasi otot lain memiliki manfaat kesehatan dalam 3 cara yaitu:

1. Menggunakan efek PMR untuk memanipulasi respon-respon otonomik.

2. Meningkatkan atau mengaktifasi produksi opiat (endogen).

3. Meningkatkan fungsi imun secara optimal (Mackereth \& Tomlinson, 2017). 
Respons otonom menentukan apakah tubuh perlu terlibat dalam skenario 'fight-or-flight' atau 'rest-and-digest' atau sebuah keadaan di antara dua ekstrem ini. Pembagian simpatis dari sistem saraf otonom (ANS), yang terkait dengan respons 'flight-or-fight', memobilisasi tubuh dalam kondisi darurat dan stres. Banyak tanggapan ini tidak segera terlihat oleh kesadaran kita (Hallman \& Lyskov, 2012). Secara fisik, aliran darah dialihkan dari proses pencernaan ke otot polos, denyut jantung dan tekanan darah meningkat, dengan proses ini dipicu oleh peningkatan katekolamin sirkulasi, yang meliputi adrenalin dan noradrenalin (Mackereth \& Tomlinson, 2017). Terkait dengan respons stres adalah pelepasan kortisol, yang memobilisasi cadangan energi, meningkatkan sensitivitas jaringan ke neurotransmitter dan menghambat respon kekebalan dan inflamasi. Teknik PMR menggentarkan gairah simpatik dengan melatih individu untuk mengurangi kebutuhan oksigen, yang dicapai dengan pelepasan berulang ketegangan otot yang dikombinasikan dengan perlambatan respirasi. Hal ini membuat intervensi terapeutik yang berguna untuk keadaan panik, fobia dan kegelisahan (Kusumo, 2017).

Penting untuk kesejahteraan, opioid endogen, seperti enkephalin, dynorphins, endomorphins dan $\beta$ endorphin, telah ditemukan memiliki berbagai efek, termasuk analgesik, anti-inflamasi dan bronkodilatasi. Senyawa dan situs reseptornya telah ditemukan di jaringan kekebalan tubuh. Telah dikemukakan bahwa opioid memainkan peran penting dalam memodulasi respons stres. Telah dicatat bahwa produksi opioid meningkat pada orang dewasa yang berolahraga secara teratur dan berkurang pada orang dewasa dengan masalah kesehatan yang terus-menerus seperti sindrom kelelahan kronis. Dalam percobaan laboratorium $(\mathrm{n}=$ 32) untuk menentukan peran opioid endogen dalam efek pelatihan PMR. yang secara signifikan mengurangi tekanan diastolik, namun bila blokade opioid diberikan, hal itu bertentangan dengan latihan PMR (Mackereth \& Tomlinson, 2017; Kapitzke et al., 2005).

Kontraindikasi yang mungkin terjadi seperti cedera akut atau ketidaknyamanan muskuloskeletal dan penyakit jantung berat/akut (Kumar \& Cannon, 2009). Latihan PMR dapat menimbulkan peningkatan kondisi relaks yang dapat menyebabkan hipotensi sehingga perlu memeriksa tekanan darah untuk mengidentifikasi kecenderangan hipotensi (Lindquist et al., 2014). Ada perbedaan yang signifikan secara statistik dalam skor kualitas hidup antara kelompok intervensi dan kelompok kontrol setelah intervensi sehingga PMR menyebabkan peningkatan dan meningkatkan kualitas hidup dan kesehatan pada pasien kelompok intervensi. Tapi, tidak ada perubahan yang dicatat dalam skor kualitas hidup pasien dalam kelompok kontrol (Rokhman etal., 2018). Hasil juga menunjukkan tidak ada perbedaan yang signifikan pada skor rata-rata fatigue severity sebelum intervensi antara kelompok intervensi dan kelompok kontrol, tetapi ada perbedaan yang signifikan secara statistik pada fatigue severity antara kelompok intervensi dan kelompok kontrol. Dokumentasi kegiatan Pengabdian kepada masyarakat disajikan pada Gambar 1 sampai 4.

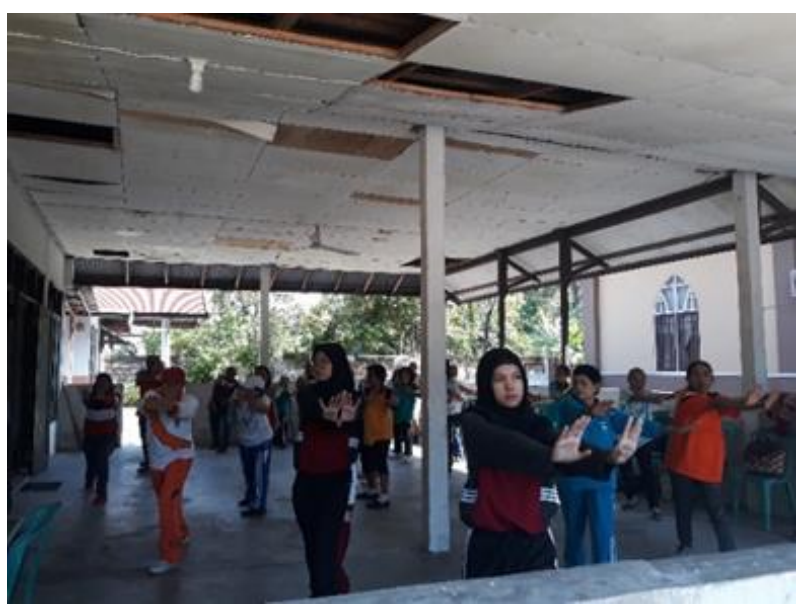

Gambar 1. Kegiatan Senam oleh Tim Pengabdian Masyarakat diikuti oleh peserta 


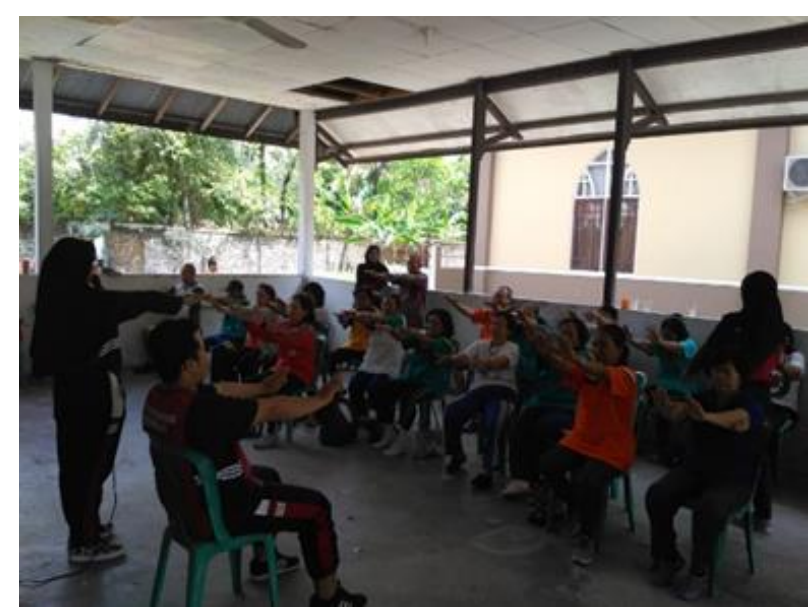

Gambar 2. Praktik Relaksasi Otot Progresif Tangan

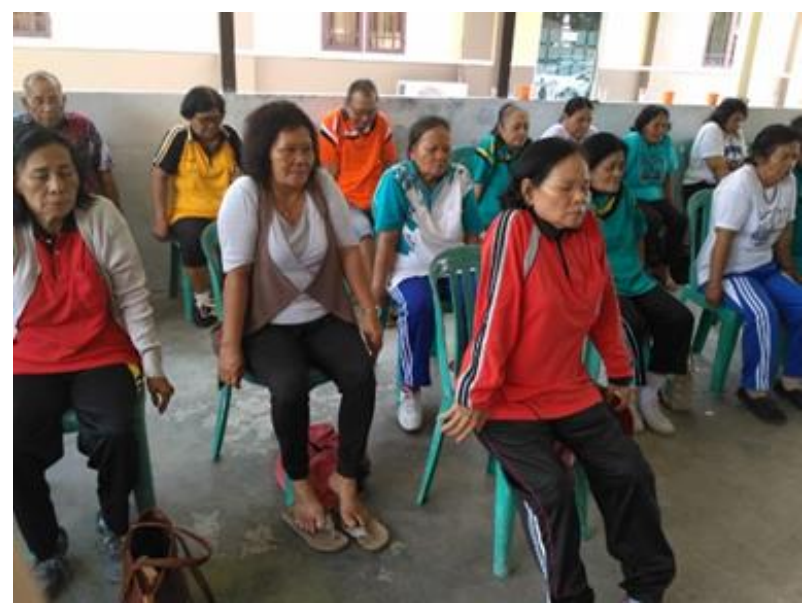

Gambar 3. Praktik Relaksasi Otot Progresif Kaki

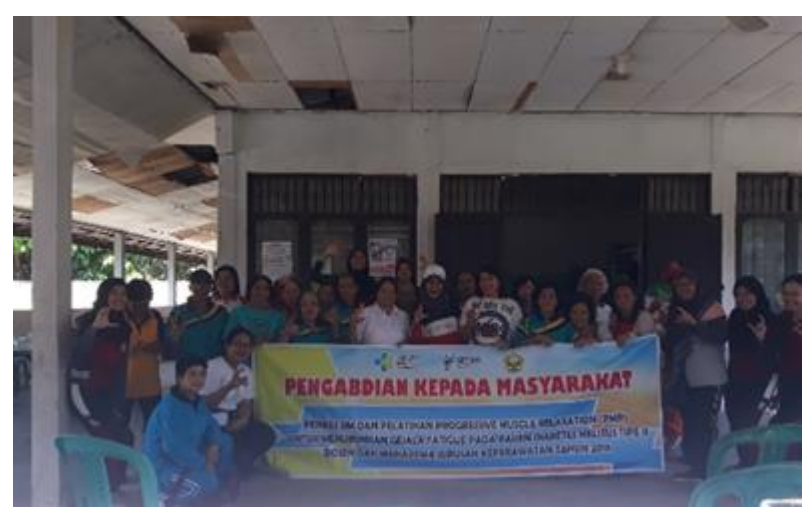

Gambar 4. Tim Pelaksana Pengabdian Masyarakat beserta Peserta

\section{KESIMPULAN}

Terapi nonfarmakologi salah satunya relaksasi otot progresif merupakan prosedur yang dapat diajarkan dan diterapkan oleh pasien yang mengalami penyakit diabetes melitus untuk mengurangi gejala fatigue. Berdasarkan penelitian yang telah banyak dilakukan, PMR telah menunjukkan manfaat dalam menurunkan kadar glukosa darah dan gejala fatigue sehingga PMR relatif aman untuk dilakukan secara mandiri oleh pasien.

\section{UCAPAN TERIMA KASIH}

Penulis mengucapkan penghargaan yang tiada terhingga kepada semua pihak yang telah membantu sehingga kegiatan pengabdian kepada masyarakat ini dapat terlaksana dengan baik, khususnya kepada Direktur Poltekkes Kemenkes Palangka Raya atas bantuan dana yang telah diberikan, Kepala Puskesmas Puskesmas Kayon, Pembimbing Klinik beserta Staf, Kader Posbindu Bethesda, Peserta Pengabmas dan Mahasiswa Prodi D-IV Keperawatan Poltekkes Kemenkes Palangka Raya.

\section{REFERENSI}

American Diabetes Association. 2009. Diagnosis and Classification of Diabetes Mellitus. Diabetes Care. 34(Suppl 1):S62-S69. https://dx.doi.org/10.2337/dc11-S062

Amir, S.M.J., Wungouw, H., Pangemanan, D. 2015. Kadar Glukosa Darah Sewaktu pada Pasien Diabetes Melitus Tipe 2 di Puskesmas Bahu Kota Manado. eBiomedik. 3(1):32-40. https://doi.org/10.35790/ebm.3.1.2015.6505

Antoni, A., Dharmajaya, R., Harahap, I.A. 2016. Pengaruh Progressive Muscle Relaxation terhadap Gejala Fatigue pada Klien Diabetes Melitus Tipe 2. Jurnal Kesehatan Ilmiah Indonesia (Indonesian Health Scientific Journal). 1(1):7-13.

Asif, M. 2014. The prevention and control the type-2 diabetes by changing lifestyle and dietary pattern. Journal of Education and Health Promotion. https://dx.doi.org/10.4103/2277-9531.127541

Danismaya, I. Pengaruh Teknik Relaksasi Yoga Terhadap Fatique Penderita Kanker Pasca 
Kemoterapi di R S Hasan Sadikin Bandung. Gaster. 5(1):366-378.

Fahra, R.U., Widayati, N., Sutawardana, J.H. 2017. Hubungan Peran Perawat sebagai Edukator dengan Perawatan Diri Pasien Diabetes Melitus Tipe 2 di Poli Penyakit Dalam Rumah Sakit Bina Sehat Jember. NurseLine Journal. 2(1):61-72.

Fritschi, C., Quinn, L., Hacker, E.D., Penckofer, S.M., Wang, E., Foreman, M., Ferrans, C.E. 2012. Fatigue in Women with Type 2 Diabetes. The Diabetes Educator. 38(5):662-672. https://dx.doi.org/10.1177/014572171245092 5

Hallman, D.M., Lyskov, E. 2012. Autonomic Regulation in Musculoskeletal Pain. In Ghosh, S. (Ed). Pain in Perspective. London: IntechOpen. https://doi.org/10.5772/51086

Kapitzke, D., Vetter, I., Cabot, P.J. 2005. Endogenous opioid analgesia in peripheral tissues and the clinical implications for pain control. Therapeutics and Clinical Risk Management. 1(4):279-297.

Kristianungrum, Y., Budiyani, K. 2011. Dukungan Keluarga dan Kepatuhan Minum Obat pada Orang dengan Diabetes Melitus. Psycho Idea. 9(2):47-59.

http://dx.doi.org/10.30595/psychoidea.v9i2. 249

Kumar, A., Cannon, C.P. 2009. Acute Coronary Syndromes: Diagnosis and Management, Part I. Mayo Clinic Proceedings. 84(10): 917-938. https://doi.org/10.4065/84.10.917

Kunaryanti, K., Andriyani, A., Wulandari, R. 2018. Hubungan Tingkat Pengetahuan tentang Diabetes Mellitus dengan Perilaku Mengontrol Gula Darah pada Pasien Diabetes Mellitus Rawat Jalan di RSUD Dr. Moewardi Surakarta. Jurnal Kesehatan. 11(1):49-56. https://doi.org/10.23917/jurnal/kesehatan.v 11 i1.7007

Kusumo, M.P. 2017. Pengaruh Komunikasi Terapeutik Perawat Terhadap Kepuasan Pasien di Rawat Jalan RSUD Jogja. JMMR (Jurnal Medicoeticolegal dan Manajemen Rumah Sakit). 6(1):72-81.

https://doi.org/10.18196/jmmr.6130
Lindquist, R., Snyder, M., Tracy, M.F. 2014. Complementary \& Alternative Therapies in Nursing. Seventh Edition. New York: Springer Publishing Company.

Livana, P.H., Daulima, N.H.C., Mustikasari. 2018. Relaksasi Otot Progresif Menurunkan Stres Keluarga yang Merawat Pasien Gangguan Jiwa. Jurnal Keperawatan Indonesia. 21(1):51-59. https://doi.org/10.7454/jki.v21i1.362

Mackereth, P.A., Tomlinson, L. 2017. Progressive Muscle Relaxation: A Remarkable Tool for Therapist and Patients. Amsterdam: Elsevier.

Rokhman, A., Ahsan, Supriati, L. 2018. Pengaruh Terapi Progressive Muscle Relaxation terhadap Kecemasan Dan Kualitas Hidup pada Pasien Diabetes Mellitus Tipe 2 di RS Muhammadiyah Lamongan. Jurnal Riset Kesehatan Nasional. 2(1):45-58.

Rudijanto, A. 2014. Keterangan Ringkas tentang Diabetes Mellitus Kencing Manis. Malang: Danar Wijaya.

Seo, Y.M., Hahm, J.R., Kim, T.K., Choi, W.H. 2015. Factors affecting fatigue in patients with type II diabetes mellitus in Korea. Asian Nursing Research. 9(1):60-64. https://doi.org/10.1016/j.anr.2014.09.004

Setiawan, M. 2011.Pre-Diabetes dan Peran HbA1c dalam Skrining dan Diagnosis Awal Diabetes Melitus. Saintika Medika: Jurnal Ilmu Kesehatan dan Kedokteran Keluarga. 7(1):57-64. https://doi.org/10.22219/sm.v7i1.1087

Soegondo, S., Soewondo, P., Subekti, I. 2007. Penatalaksanaan Diabetes Melitus Terpadu. Jakarta: Balai Penerbit Fakultas Kedokteran Universitas Indonesia. 